\title{
Application Analysis on Information Promotion System of Hollow Village Renovation in Hilly Area
}

\author{
LU ZHANG \\ Shaanxi Provincial Land Engineering Construction Group CO., LTD., \\ Institute of Land Engineering \& Technology, Shaanxi Land Construction group, CO., LTD., Xi'an, \\ Shaanxi 710075, China
}

Keywords: Hilly area, Hollow village, Informatization, Integration

\begin{abstract}
This is complex topography, fragile ecosystems and difficult to land remediation in hilly hollow village. In this paper, mainly through the establishment and analysis of the information promotion system of hollow village remediation in hilly areas to illustrate the four technologies integration of hilly hollow village remediation (remediation to the field technology, remediation planning and design technology, site consolidation technology and environmental ecology reconstruction technology), so as to achieve the better promotion and application in same hollow village remediation areas.
\end{abstract}

\section{The Necessity of Establishing an Information Extension System of Hollow Village Improvement}

In the face of complex land issues in hilly area, problems such as insufficient fertility of new cultivated land, poor stability of soil mass, many types of homesteads, backward economic development, extensive land use, complex topography and terrain, inconvenient transportation, imperfect farmland supporting facilities, fragile ecological environment and serious soil erosion. Any single technology, such as land remediation, land consolidation, planning and design, or ecological environment reconstruction, cannot effectively solves the complex hollow village problems, and must through the integration of these technologies, the greatest utility of each technology can be brought into play.

In the hilly areas, there are many types of hollow homesteads, many ancient buildings and ancient villages. While ensuring the continuity of rural culture and maximizing the original appearance of the village, the land remediation technology and remediation planning and design techniques must be applied at the same time to improve land quality as much as possible and enhance soil fertility. Faced with these problems of low density of residence, complex topography, and inaccessible traffic of hollow village in hilly areas, we need to use both planning and design techniques and site preparation techniques to improve residents' production and living needs. Faced with these problems of fragile ecological environment and low vegetation coverage, we need to comprehensively carry out site reorganization and reconstruction of the ecological environment so as to ensure the formation of ecologically friendly and beautifully landscaped villages. Each of the above four technologies is independent of each other, but at the same time, the four technologies for the renovation of hollow village land in hilly regions are both heavy and complex. Among them, the planning and designing technology contains a variety of data with graphical and attribute features, whose compilation, approval, and implementation involve a large number of spatial data such as maps and indicators, and various potential calculations, analysis, and drawing of related maps are required. The management and integration of relevant information such as soil physical and chemical properties, site conditions, and eco-environmental restriction factors related to land remediation technology, site preparation technology, and ecological reconstruction technology also require information integration. Therefore, the integration of hollow village remediation technology in hilly regions cannot be separated from the modern methods of information systems. 


\section{The Connotation of Hollow Village Renovation Techniques in Hilly Regions}

Based on the complex terrain and ecologically fragile geographical features of hollow villages in hilly regions and the need for scientific and technological innovations, in response to these problems of backward economic development, scattered living areas, inconvenient transportation, extensive land use, large per capita land use, and high degree of hollowing in hollow villages in hilly regions, we systematically carried out research on planning and design techniques for hollow village renovation in hilly areas. In response to these problems of insufficient fertility of new cultivated land, many types of housing sites, and frequent natural disasters in hollow villages in hilly areas, we carried out the research on the remediation technology of abandoned homesteads (old cave dwellings, adobe houses, brick-and-mortar buildings and so on). For the feature that complicated terrain geology, many types of empty homesteads and the high degree of hollowing in hilly areas, we studied (discarded villages) site preparation techniques. In response to the characteristics of low plant cover, water pollution, soil pollution and other ecological environment are fragile of hollow villages in hilly regions; we have completed the study of the ecological reconstruction of hollow villages.

In view of these characteristics of hilly regions (Table 1), technical integration of the above four technologies was carried out, and finally, a complete set of technological achievements have been formed such as technical standards and technical application system platforms for the renovation of hollow villages in hilly regions, and which are popularized and applied.

Table 1 The characteristics and supporting techniques of hollow villages in hilly regions

\begin{tabular}{|c|c|c|}
\hline Remediation key technologies & Hollow village features in hilly area & Remediation research contents \\
\hline \multirow{3}{*}{$\begin{array}{l}\text { renovation and returning on } \\
\text { field technology }\end{array}$} & Insufficient fertility of cultivated land & Fertility Improvement Technology \\
\hline & Various types of homestead & $\begin{array}{c}\text { Abandoned homestead demolition } \\
\text { technology }\end{array}$ \\
\hline & Frequent natural disasters & Soil mass reconstruction technology \\
\hline \multirow{2}{*}{$\begin{array}{l}\text { Renovation planning and } \\
\text { design technology }\end{array}$} & $\begin{array}{c}\text { Backward economic development } \\
\text { Lively scattered } \\
\text { inconvenient traffic }\end{array}$ & $\begin{array}{l}\text { Spatially integrated planning technology } \\
\text { Intensive land use technology } \\
\text { Public facilities co-location technology }\end{array}$ \\
\hline & $\begin{array}{c}\text { Extensive land use, large per capita land } \\
\text { use }\end{array}$ & Central village site selection technology \\
\hline \multirow{3}{*}{ Site finishing technology } & Complex terrain and geology & Geological disaster technology \\
\hline & Lagging farmland facilities & Storage and drainage technology \\
\hline & High degree of hollowing & Drone Survey Technology \\
\hline \multirow{4}{*}{$\begin{array}{l}\text { Environmental ecological } \\
\text { reconstruction technology }\end{array}$} & Low plant coverage & $\begin{array}{l}\text { Ecological landscape construction and } \\
\text { restoration technology }\end{array}$ \\
\hline & Fragile ecological environment & $\begin{array}{c}\text { Human settlement reconstruction } \\
\text { technology }\end{array}$ \\
\hline & $\begin{array}{l}\text { Water pollution } \\
\text { soil pollution }\end{array}$ & $\begin{array}{l}\text { Water treatment technology } \\
\text { Soil Improvement Technology }\end{array}$ \\
\hline & Many ancient villages & $\begin{array}{l}\text { Traditional building protection and } \\
\text { restoration technology }\end{array}$ \\
\hline
\end{tabular}

\section{Design and Implementation of Informatization Extension System}

In the construction of hollow village renovation technology integration system in hilly areas, the overall design of the system must first be completed, and then the basic structure should be built, a reasonable implementation technology should be selected, and finally the platform should be implemented.

\section{System Design}

The main goals of the system design are to establish a practical, advanced, efficient, and reliable hollow village integrated renovation integrated platform in hilly regions with using knowledge visualization integrated technology, and facing service technology, 3S technology (remote sensing 
technology, geographic information system technology, global positioning system technology), database management technology and computer network technology and so on, which to meet the application and needs of land remediation technology, site preparation technology, planning and design technology and ecological environment reconstruction technology of hollow villages in hilly areas under the new form of national economic development.

The system design is mainly based on these principles of safety, stability, simplicity, and practicality, implements these guiding ideologies of application-oriented, advanced development and practical results, carries out system design and development to ensure that the system construction both in line with the actual and meet the requirements of use ${ }^{[1]}$.

\section{Overall Structure}

\section{System Logical Architecture}

The overall logical framework of the integrated platform for hollow village renovation in hilly regions is divided into four parts: hardware support layer, software support layer, integrated integration layer and application layer. As shown in Figure 1.

(1) Basic hardware platform. The basic hardware platform is a basic control equipment mainly that is based on the basic network, servers, and personal computers (Personal Computer, PC), to provide hardware support equipment for hollow villages renovation integrated platform system in the whole hilly areas. The selection of hardware platforms is based on international advanced high-grade selection standards.

(2) Basic software layer. The basic data layer is mainly constructed by a basic database, an operating system and so on.

(3) Integrated integration layer. Integrate the relevant subsystems in the integrated platform for hollow village renovation in hilly areas through integrated technology to achieve data sharing and information exchange.

(4) Application layer. Base on the applications of visualization-based decision support services and browser and server architectures (B/S structures).

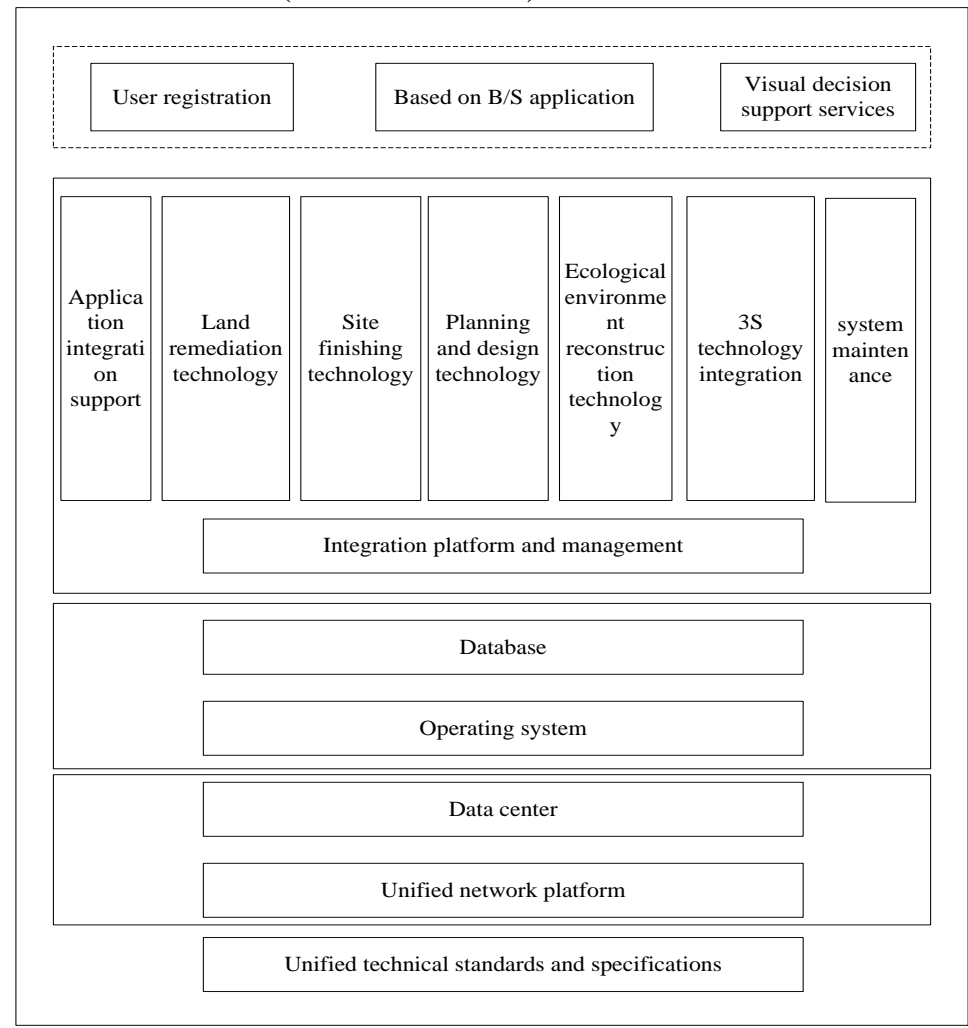

Fig. 1 The logical framework of integrated platform for hollow village renovation in hilly areas 


\section{The Main Function of the System}

The implementation of the integrated platform for hollow village renovation knowledge in hilly regions is the key to comprehensively initiating the construction of hollow village in hilly regions, which comprehensively and systematically integrated the business, data, processes, standards, and other related parts of hollow village renovation in hilly areas, built an information management informationization platform for integrating national, provincial, municipal and county integration for hollow village renovation in hilly areas.

By using modern information and network technology of hollow village knowledge comprehensive integration platform to realize the informationization of the whole management work, electronic newsletter, computer management of approval process, evaluation, monitoring, statistics and analysis of development and consolidation projects for hollow village renovation management in hilly areas, which promote the scientific, normative, transparent and impartial services for the development and consolidation of hollow villages in hilly areas.

The system involves the entire process of the hollow village renovation project from the storage record, preliminary review and budget information reporting, receiving and auditing, task assignment, technical economic review, project implementation management and file management. Users involve the county-level, municipal, provincial-level land and resources management department, the department office, the relevant business department information centre and the department finishing centre. Functionally, report and implementation information electronic declaration, business process, network management and query statistical analysis are involved.

\section{System Business Process}

Consider as a relatively independent information platform system, the hollow village renovation integrated platform includes three major parts, survey of hollow village utilization, hollow village's overall planning and design and promotion website design in hilly areas. The status survey section of the hollow villages in the hilly areas is to build the database for the results of the investigation of hollow villages in the current hilly region and the basic information needed, firstly, which include graphics, attributes, and necessary summary statistics. Then, according to the change data, the content of the library is modified in time to ensure the reality of the use of status data of hollow village in hilly areas and the use actuality of hollow villages in rural hilly areas is managed hierarchically, statistical analysis and query output.

The planning and design for hollow village renovation in hilly areas is to formulate an overall plan and special plans for the abandoned homestead, to further establish the hollow village utilization planning database assisted decision making. In the process of monitoring plan implementation, technical, administrative and legal management are implemented on the temporal and spatial changes of land use. At the same time, the benefit analysis of planning implementation is carried out. In the implementation process, the plan should be updated and improved in a timely manner, and land use should be optimized and land should be used rationally. The specific business process is shown in figure 2.

\section{Platform Realization and Protection}

The application functions of the hollow village integrated renovation integrated technology platform in hilly areas mainly include: planning and design technology, site preparation technology, land remediation technology and ecological environment reconstruction technology, which involves broader coverage and huge content. In addition, the formation of hollow villages in hilly areas has a complex social and historical background that is the result of a combination of various factors, so the renovation of hollow village will inevitably involve all aspects of social transformation and is by no means purely from a technical perspective or within a short period of time. It also requires planning and design personnel to collaborate with all parties. The relevant laws and regulations, the application of technologies and the standardization of technological advancement should be gradually established and improved. 
The comprehensive integrated platform for the hollow village renovation in hilly areas has carried out many investigations and studies, exchanges and communication with hollow villages of many villages in Shaanxi province, and has formulated plans for the comprehensive renovation of hollow villages in various hilly areas. With the knowledge visualization integrated support platform as the carrier, the overall demand for integrated platform development of hollow village renovation in hilly areas was realized. As shown in Figure 2, which shows the topographic map of the hollow village of hilly area in Bodong village, Zhuangtou Township, Chengcheng County. This knowledge integration platform provides an auxiliary remediation model for the hollow villages and provides decision-making for the rehabilitation of hollow villages in the hilly area.

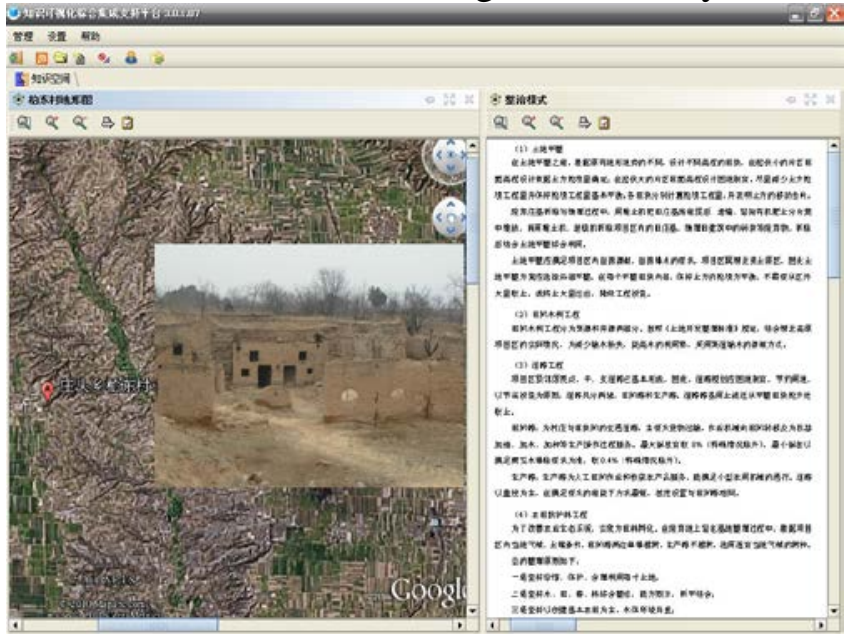

Fig. 2 The hollow village regulation model in hilly area of Yuzihe village, Chengcheng County

\section{Acknowledgement}

This work was financially supported by Shaanxi Province Land Engineering Construction Group Research Project "Moisture Characteristics and Transport Law of Mixed Media in Feld spathic sandstone and Aeolian sandy soil in Mu Us Sandy Land (DJNY2017-23)" fund.

\section{References}

[1] Han Jichang, Xie Jianchang. Study on the renovation of abandoned homesteads in rural Shaanxi [M]. Xi;an, Shaanxi Science and Technology Press. 2010.

[2] Jiang Wei, Wang Yonglin, Song Shiting. A grid architecture with P2P technology. Computer and Digital Engineering. 2010, 38 (07):58-61+69. 